\title{
Germination Temperature and the Effect of Storage Time on the Seed Viability of Zephyra elegans (Tecophilaeaceae)
}

\author{
Carlos De la Cuadra, Alexis K. Vidal' ${ }^{1}$, Patricia Peñaloza, Leví Mansur, \\ and Carlos Huenchuleo \\ Escuela de Agronomía, Pontificia Universidad Católica de Valparaíso,
Casilla 4-D, Quillota, Chile
}

Additional index words. after-ripening, Atacama Desert, geophyte, seed dormancy, seed germination, seed storage

\begin{abstract}
Zephyra elegans is a geophyte endemic to Chile that has horticultural value as a cut flower. Its natural habitat is a coastal desert climate with abundant cloud cover, little and variable precipitation, and mean monthly temperatures between 10 and $20{ }^{\circ} \mathrm{C}$. It is hypothesized that the temperature requirements for germination of $Z$. elegans seeds are similar to those of Zephyra compacta, which shares the same habitat. As it is a species from a desert climate, it can be expected that its seeds remain viable during long periods of storage. The seeds used in this study were harvested in different years from plants grown from cultivated corms of $Z$. elegans. The germination test temperatures were 10 , 15,20 , and $25^{\circ} \mathrm{C}$, and the dry storage times at room temperature $\left(20 \pm 5^{\circ} \mathrm{C}\right)$ were 4,16 , 28 , and 40 months. The temperature requirements for germination of $Z$. elegans seeds are similar to those of $Z$. compacta, which has been studied earlier, i.e., the temperature range for achieving high germination percentages is 10 to $20^{\circ} \mathrm{C}$, whereas $25^{\circ} \mathrm{C}$ can be considered supraoptimal. After-ripening of the seeds occurred during dry storage, as shown by increased germination when tested at a supraoptimal temperature. The seeds had high viability after $\mathbf{4 0}$ months of dry storage at room temperature.
\end{abstract}

Zephyra elegans is a perennial herbaceous species of horticultural value. The genus Zephyra, belongs to the Tecophilaeaceae family, is endemic to Chile and comprises Z. compacta, Zephyra cyanocrocus, Z. elegans, and Zephyra violiflora (Buerki et al., 2013; Ravenna, 1988). Zephyra elegans has fibrous corms, narrow basal lanceolate leaves, panicle inflorescence, six-petaled actinomorphic flowers with straight or wavy edges, fruit in the shape of three-sided round capsules, and ellipsoid, flattened, rough, dark brown seeds (Muñoz and Moreira, 2000; Simpson and Rudall, 1998). Its conservation status is described as out of danger (Squeo et al., 2008). It has horticultural value as a cut flower because the plant is generally neat; with floral stems longer than $40 \mathrm{~cm}$; comprising numerous flowers with a diameter of $2 \mathrm{~cm}$; a white interior and pale blue exterior; and excellent flower lifespan (Bridgen et al., 2002; Kim and Ohkawa, 2001).

The natural habitat of this species is the desert coast of northern Chile between the region of Arica and Parinacota $\left(18{ }^{\circ} \mathrm{S}\right)$ and the region of Coquimbo $\left(29^{\circ} \mathrm{S}\right.$ ) (Pinto and

\footnotetext{
Received for publication 29 Dec. 2017. Accepted for publication 23 Apr. 2018.

We gratefully acknowledge Luis Arriagada for collecting the corms of Zephyra elegans from which the seeds used in this study were obtained. ${ }^{1}$ Corresponding author. E-mail: kooichi.vidal@ pucv.cl.
}

Luebert, 2009; Ravenna et al., 1998). This habitat is mainly composed of sandy soils with a coastal desert climate and abundant cloud cover, which in accordance with the Köppen classification system would be classified as BWn (Juliá et al., 2008). As is also the case with $Z$. compacta (De la Cuadra et al., 2017), the climate in which $Z$. elegans grows experiences cloud cover and fog almost all year, little and highly variable rainfall from year to year, mean monthly temperatures from 10 to $20^{\circ} \mathrm{C}$, and a mean daily temperature oscillation of $7.5{ }^{\circ} \mathrm{C}$. According to Antonioletti et al. (1972), the seasonality of this climate is defined by the frequency of the cloud cover and fogs, and by rainfall on 1-4 $d$ in winter, rather than by annual changes in temperature. It is important to note that the El Niño-Southern Oscillation phenomenon occurs in this region, where unusually high rainfall $(\geq 15 \mathrm{~mm})$ leads to the emergence of more than 200 species of annual and geophyte plants, including Z. elegans (Gutiérrez, 2008; Vidiella et al., 1999).

Zephyra elegans may have survival strategies to take advantage of the sporadic years in which water from precipitation is available and to survive the dry years with little or no precipitation, as is common among desert species (Figueroa et al., 2004). According to Baskin and Baskin (2014), the main survival strategies of desert species include the formation of persistent seed banks and latency mechanisms that allow the seeds to remain viable for long periods until conditions for germination and propagation of the plants become favorable.

Considering that $Z$. compacta lives in the same habitat as $Z$. elegans and that its germination temperature requirements are known (De la Cuadra et al., 2017), it can be hypothesized that the germination temperature requirements of $Z$. elegans seeds are similar to those of $Z$. compacta. In other words, high germination percentages can be obtained in the temperature range between 10 and $20^{\circ} \mathrm{C}$, whereas $15^{\circ} \mathrm{C}$ can be considered optimum and $25^{\circ} \mathrm{C}$ will inhibit germination. Because Z. elegans is a desert species, its seeds should also remain viable in dry storage for more than 1 year.

Based on the previous text, the objective of the present study is to determine the optimum temperature for germination, while also assessing the effect of storage time on the seed viability of $Z$. elegans.

\section{Materials and Methods}

The seeds came from 45 corms of $Z$. elegans collected in 2007 in the coastal desert region of the Atacama Desert, Chile, between Huasco $\left(28^{\circ} 30^{\prime} \mathrm{S}, 71^{\circ} 15^{\prime} \mathrm{W}\right)$ and Bahía Sarco $\left(28^{\circ} 51^{\prime} \mathrm{S}, 71^{\circ} 27^{\prime} \mathrm{W}\right)$. In 2009 , the corms were grown in Viña del Mar, Chile $\left(33^{\circ} 00^{\prime} \mathrm{S}, 71^{\circ} 30^{\prime} \mathrm{W}\right)$, and the seeds were then harvested and stored for 28 and 40 months until germination tests were carried out. In 2011, the same corms were grown in Quillota, Chile $\left(32^{\circ} 54^{\prime} \mathrm{S}, 71^{\circ} 12^{\prime} \mathrm{W}\right)$, and the seeds were harvested and stored for 4 and 16 months until germination tests were carried out. All seeds were stored in paper envelopes at room temperature $\left[20 \pm 5{ }^{\circ} \mathrm{C}\right.$; $50 \%$ to $70 \%$ relative humidity $(\mathrm{RH})$; darkness] at the Laboratory of Phytogenetics at the School of Agronomy of the Faculty of Agricultural and Food Sciences, at the Pontificia Universidad Católica de Valparaíso, located in Quillota, Chile.

The germination tests were carried out in chambers at temperatures of $10,15,20$, and $25 \pm 2{ }^{\circ} \mathrm{C}$, in darkness, with seeds that had been stored for $4,16,28$, and 40 months. After storage, the seeds were disinfected for $3 \mathrm{~min}$ in $1 \%$ Captan ${ }^{\circledR}$ solution [Captan ${ }^{\circledR}$ 50WP; $N$-(trichloromethylthio)4-cyclohexene-1,2-dicarboximide; Arysta LifeScience North America, Cary, NC] and then rinsed three times. Each treatment consisted of 200 seeds distributed on filter paper wetted with $4 \mathrm{~mL}$ of water in four petri dishes $(9 \mathrm{~cm}$ in diameter) with 50 seeds in each dish. The germination results were recorded every 2 days for a maximum period of 6 weeks. Seeds were exposed to normal light while checking germination. A seed was considered germinated once the radicle had emerged $2 \mathrm{~mm}$. If the seeds did not reach $85 \%$ germination for at least one of the test temperatures for each storage time, the viability of the nongerminated seeds was checked using the tetrazolium test (International Seed Testing Association, 2003). 
The germination data for each treatment were fitted to the event-time model $\mathrm{F}(t)=d /(1+$ $\left.\exp \left[b\left\{\log (t)-\log \left(t_{50}\right)\right\}\right]\right)$ used by Ritz et al. (2013), where $\mathrm{F}$ defines a proper cumulative distribution function, which for each time point $t \geq 0$ returns the fraction of seeds that has already germinated. The upper limit parameter $d$ denotes the proportion of seeds that geminated during the experiment of the total number of seeds present at the beginning of the experiment. The parameter $b$ is proportional to the slope of $\mathrm{F}$ at time $t$ equal to the parameter $t_{50}$, the time at which $50 \%$ of all seeds germinated during the experiment have germinated.

Parameter estimation of the event-time model for each treatment was carried out using the extension package for the software environment R (Ritz and Streibig, 2005). The statistical test used for comparisons was the test of equality of two means when population variances are not equal at $P \leq 0.05$ (Ritz and Streibig, 2005).

\section{Results}

As shown in Figure 1, germination curves for the different treatments were fitted to the model used by Ritz et al. (2013). The highest values of parameter $d$ were obtained at 10,15 , and $20^{\circ} \mathrm{C}$. Irrespective of the storage time of 4,16 , or 28 months, in the range of 10 to $20{ }^{\circ} \mathrm{C}$, values of $d \geq 93 \%$ were obtained. Based on the values of the parameter $t_{50}$, within the germination range of 10 to $20^{\circ} \mathrm{C}$, the optimum temperature appears to be $15{ }^{\circ} \mathrm{C}$. Regarding the nature of germination in relation to the value of parameter $b$, the uniformity tended to be higher, i.e., lower values of $b$, at lower temperatures (Table 1).

At $25^{\circ} \mathrm{C}$, storage time was seen to affect germination. Seeds stored for 4 months gave a maximum germination percentage $(d)$ of $15 \%$, and as storage time increased germination reached $90 \%$. Following a similar pattern, the value of $t_{50}$ decreased and the value of $b$ increased from 16 months of storage, giving germination curves a more vertical shape as storage time increased (Fig. 2). Germinating at $25{ }^{\circ} \mathrm{C}$, the seeds stored for 28 and 40 months gave similar values for $d$, $t_{50}$, and $b$. The value of $b$ for seeds stored for 28 and 40 months increased, in some cases reaching the same level as seeds germinated in the range of 10 to $20^{\circ} \mathrm{C}$ (Table 1).

\section{Discussion}

Seeds were incubated in darkness and checking for germination exposed them to room light. Independent of the germination temperature and storage time, with the exception of $25{ }^{\circ} \mathrm{C}$ and 4 months' storage, germination was high $(d>85 \%)$. Though the light requirement for germination is unknown, any such requirement would have been fulfilled while germination was being checked. Although germination at $25{ }^{\circ} \mathrm{C}$ of seeds stored for 4 months reached only $18 \%$, seeds from the same storage time incubated at temperatures from 10 to $20^{\circ} \mathrm{C}$ saw germination
Table 1. Parameter estimates (sE in brackets) of the log-logistic model $d /\left(1+\exp \left[b\left\{\log (t)-\log \left(t_{50}\right)\right\}\right]\right)$ obtained by fitting the event-time model. The upper limit parameter $d$ denotes the proportion of Zephyra elegans seeds that germinated during the experiment, parameter $t_{50}$ denotes the time at which $50 \%$ of the seeds that germinated during the experiment had germinated, and parameter $b$ denotes the slope of the germination curve at time $t_{50}$.

\begin{tabular}{|c|c|c|c|}
\hline $\begin{array}{l}\text { Germ. } \\
\mathrm{T}^{\circ}\end{array}$ & $\begin{array}{c}d \\
\text { Upper limit }\end{array}$ & $\begin{array}{c}t_{50} \\
50 \% \text { germ. }\end{array}$ & $\begin{array}{c}b \\
\text { Slope }\end{array}$ \\
\hline \multicolumn{4}{|c|}{ Storage time at $20^{\circ} \mathrm{C}: 4 \mathrm{mo}}$. \\
\hline $10^{\circ} \mathrm{C}$ & 98 (1) a A & $14.5(0.2) \mathrm{c} \mathrm{I}$ & $-8.0(0.5)$ a $\mathrm{AB}$ \\
\hline $15^{\circ} \mathrm{C}$ & 95 (2) a $A B C D$ & $6.8(0.2)$ a $\mathrm{A}$ & $-5.8(0.4) \mathrm{b} \mathrm{DE}$ \\
\hline $20{ }^{\circ} \mathrm{C}$ & 95 (2) a $\mathrm{ABCD}$ & $11.8(0.3) \mathrm{b} \mathrm{G}$ & $-4.9(0.3) \mathrm{b} E F$ \\
\hline $25^{\circ} \mathrm{C}$ & $18(3) \mathrm{b} \mathrm{E}$ & $36.9(2.9) \mathrm{d} \mathrm{K}$ & $-5.5(1.2) \mathrm{ab}$ BCDEFG \\
\hline \multicolumn{4}{|c|}{ Storage time at $20^{\circ} \mathrm{C}: 16 \mathrm{mo}}$. \\
\hline $10^{\circ} \mathrm{C}$ & $96(1) \mathrm{ab} \mathrm{ABC}$ & $13.2(0.2) \mathrm{c} \mathrm{H}$ & $-7.7(0.5)$ ab ABC \\
\hline $15^{\circ} \mathrm{C}$ & 98 (1) a A & $8.9(0.2) \mathrm{b} \mathrm{DE}$ & $-6.8(0.5) \mathrm{b}$ BCD \\
\hline $20^{\circ} \mathrm{C}$ & 98 (1) a $\mathrm{AB}$ & $8.3(0.1)$ a BC & $-8.2(0.6)$ a $\mathrm{A}$ \\
\hline $25^{\circ} \mathrm{C}$ & $88(3)$ b CD & $18.8(1.3) \mathrm{d} \mathrm{J}$ & $-2.4(0.2) \mathrm{c} \mathrm{I}$ \\
\hline \multicolumn{4}{|c|}{ Storage time at $20^{\circ} \mathrm{C}: 28 \mathrm{mo}}$. \\
\hline $10^{\circ} \mathrm{C}$ & $93(2)$ ab BCD & $17.8(0.3) \mathrm{d} \mathrm{J}$ & $-8.9(0.6)$ a $\mathrm{A}$ \\
\hline $15^{\circ} \mathrm{C}$ & 95 (2) ab ABCD & $7.9(0.2)$ a B & $-5.0(0.3) \mathrm{c} E F$ \\
\hline $20{ }^{\circ} \mathrm{C}$ & 97 (1) a $\mathrm{ABC}$ & $8.6(0.2)$ b CD & $-6.4(0.4) b \mathrm{CD}$ \\
\hline $25^{\circ} \mathrm{C}$ & 90 (2) B D & $10.5(0.3)$ c F & $-4.1(0.3) \mathrm{c} \mathrm{FH}$ \\
\hline \multicolumn{4}{|c|}{ Storage time at $20^{\circ} \mathrm{C}: 40 \mathrm{mo}$. } \\
\hline $25^{\circ} \mathrm{C}$ & $90(2) \mathrm{D}$ & $9.5(0.4) \mathrm{EF}$ & $-3.5(0.2) \mathrm{GH}$ \\
\hline
\end{tabular}

${ }^{\mathrm{z}}$ For each storage time, mean values within a column followed by the same lowercase letter do not differ significantly $(P \leq 0.05)$ according to a test of equality of two means when population variances are not equal. Mean values within a column followed by the same capital letter do not differ significantly $(P \leq$ 0.05 ) according to a test of equality of two means when population variances are not equal.

higher than $95 \%$, and therefore the viability test was not performed.

Germination of $Z$. elegans responded to temperature in a way that was consistent with the climate characteristics of its habitat. $Z$. elegans has a temperature range for high germination percentages of 10 to $20{ }^{\circ} \mathrm{C}$, which coincides with temperatures that occur throughout the year in its natural habitat (Juliá et al., 2008). The lack of a single optimum temperature supports the idea that the seasonality of the coastal desert region of the Atacama is not defined by temperature variation but by the frequency of cloud cover, fog and rainfall (Antonioletti et al., 1972; Vidiella and Armesto, 1989). As with many desert species, germination is associated more with water availability than with temperature (Black et al., 2006).

At $25{ }^{\circ} \mathrm{C}$, germination performance was found to depend on storage time. Germination of seeds stored for 4 months was $18 \%$, after an incubation period of 8 weeks in darkness. A similar result, germination did not exceed $40 \%$, was observed when germinating seeds in tissue culture medium under in vitro conditions, in darkness and at the same temperature of $25^{\circ} \mathrm{C}$ (Vidal et al., 2012). For longer storage times of 16,28 , and 40 months, germination was over $88 \%$, implying that $25^{\circ} \mathrm{C}$ is a supraoptimal germination temperature.

Other species from the same habitat show similar responses. Zephyra compacta, for example, has a high germination (over $85 \%$ ) in the temperature range from 10 to $20{ }^{\circ} \mathrm{C}$, and an optimum germination temperature of $15{ }^{\circ} \mathrm{C}$ (De la Cuadra et al., 2017). Other geophyte herbaceous species native to Chile such as Conanthera campanulata (C. De la Cuadra, unpublished data), Leucocoryne dimorphopetala (De la Cuadra et al., 2016), and Pasithea coerulea (Jara et al., 2006; Schiappacasse et al., 2005) achieve

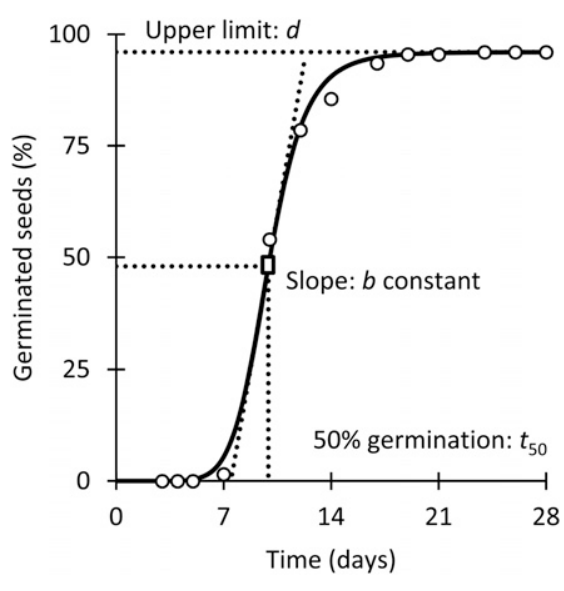

Fig. 1. Example of typical germination curves fitted to the event-time model (solid line). According to Ritz et al. (2013), the model equation is $d /\left(1+\exp \left[b\left\{\log (t)-\log \left(t_{50}\right)\right\}\right]\right)$, where $t_{50}$ is the time to reach $50 \%$ germination relative to the maximum germination percentage, which is the upper limit $d$ of the germination curve. The slope of the germination curve at time $t_{50}$ is proportional to $b$ (with a proportionality constant that depends on $d$ and $t_{50}$ ). The interpretations of the parameter estimates are shown with dotted lines in the figure. Seeds of Zephyra elegans stored for 4 months and germinated at $15^{\circ} \mathrm{C}$.

high germination at a narrower temperature range of 10 to $15^{\circ} \mathrm{C}$.

The viability of $Z$. elegans seeds was unaffected by storage at room temperature for up to 40 months. As with $Z$. compacta (De la Cuadra et al., 2017), germination of Z. elegans in the temperature range of 10 to $20{ }^{\circ} \mathrm{C}$ led to germination values of above $90 \%$ for seeds stored for 28 months at room temperature. Thus, the survival strategy of Z. elegans includes corm formation (Yañez 

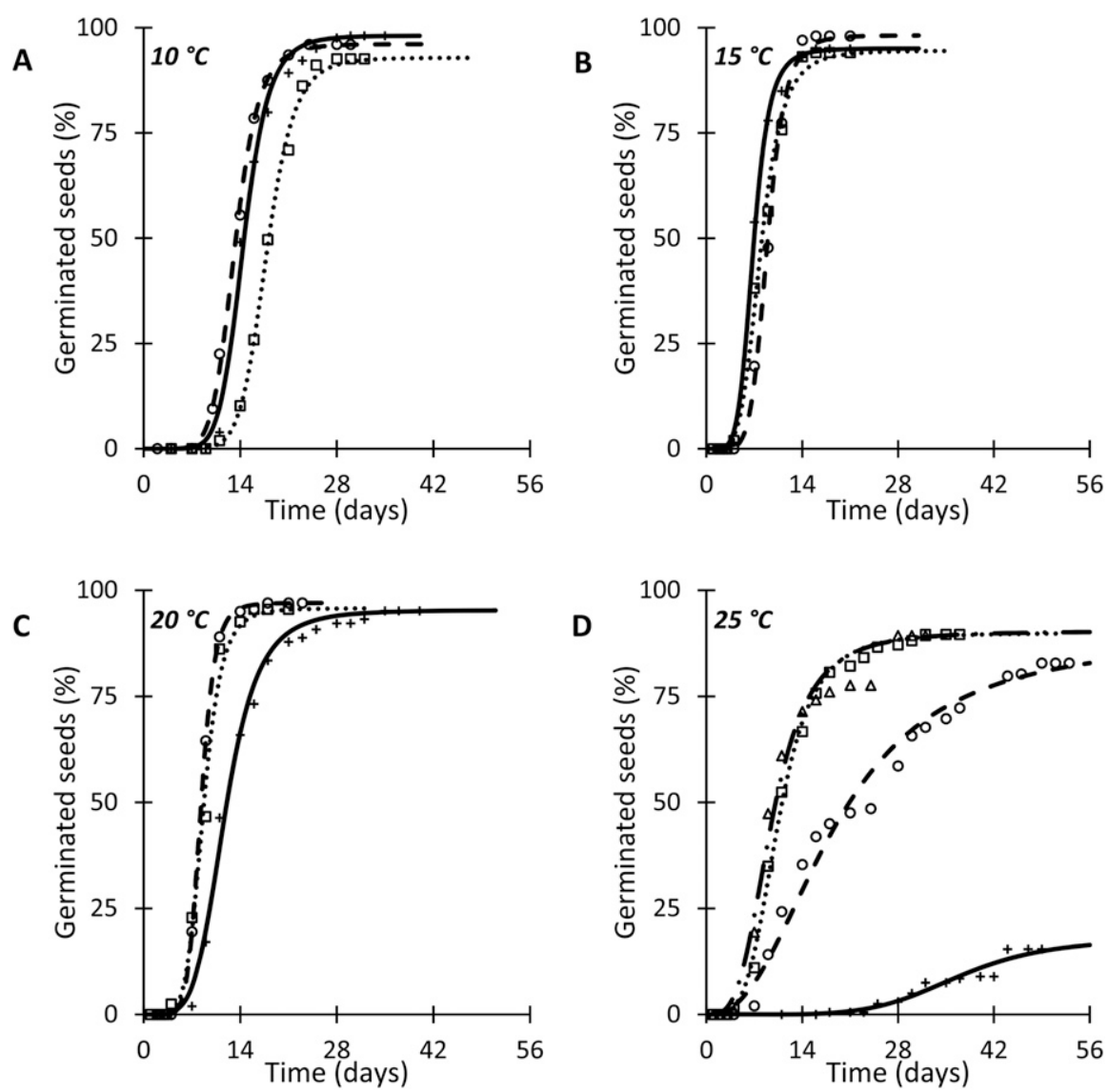

Fig. 2. Effect of storage time at $20 \pm 5^{\circ} \mathrm{C}$ for 4 months (solid line, + ), 16 months (dash line, $\bigcirc$ ), 28 months (dot line, $\square$ ), and 40 months (dash and dot line, $\Delta$ ) on the germination of Zephyra elegans seeds at temperatures of $10(\mathbf{A}), 15(\mathbf{B}), 20(\mathbf{C})$, and $25^{\circ} \mathrm{C}(\mathbf{D})$ in darkness. Lines represent germination curves fitted to the event-time model and markers represent observed data.

et al., 2005) and retention of seed viability for long periods of dry storage.

Complimentary to the above, Z. elegans appears to have a seed dormancy mechanism as a survival strategy. When incubated at the supraoptimal temperature of $25^{\circ} \mathrm{C}$, germination increased with the increase in storage time, extending the germination range. This is evidence of after-ripening, which increases the temperature range for germination after seeds have been exposed to dry storage conditions at temperatures greater than $15^{\circ} \mathrm{C}$ (Finch-Savage and Leubner-Metzger, 2006). Additional evidence of after-ripening has been observed from seeds of $Z$. elegans harvested in 2015 , stored at similar conditions as the present experiment $\left(20 \pm 5{ }^{\circ} \mathrm{C}\right.$; $50 \%$ to $70 \% \mathrm{RH}$; darkness) and tested for germination at 15 and at supraoptimal temperature of $25{ }^{\circ} \mathrm{C}$. For seeds stored for 0,2 , and 4 months, germination at $15{ }^{\circ} \mathrm{C}$ was $95 \%, 91 \%$, and $94 \%$, respectively; and for seeds germinated at $25{ }^{\circ} \mathrm{C}$, values were $1 \%, 3 \%$, and $30 \%$, respectively (C. De la Cuadra, unpublished data). Considering these data in view of the dormancy classification system (Baskin and Baskin, 2004), Z. elegans seeds have type 1 nondeep physiological dormancy.

In summary, seeds of Z. elegans stored for 4-40 months have a range for optimum germination from 10 to $20{ }^{\circ} \mathrm{C}$ and a supraoptimal temperature of $25^{\circ} \mathrm{C}$. Seeds incubated at $25^{\circ} \mathrm{C}$ showed an increase in germination as the period of after-ripening increased.

\section{Literature Cited}

Antonioletti, R., H. Schneider, J.L. Borcosque, and E. Zarate. 1972. Características climáticas del Norte Chico $\left(26^{\circ}\right.$ a $33^{\circ}$ latitud sur). Instituto de Investigación de Recursos Naturales-IREN, Santiago, Chile.

Baskin, C.C. and J.M. Baskin. 2014. Seeds: Ecology, biogeography, and evolution of dormancy and germination. 2nd ed. Academic Press, San Diego, CA.

Baskin, J.M. and C.C. Baskin. 2004. A classification system for seed dormancy. Seed Sci. Res. 14:1-16.

Black, M., J.D. Bewley, and P. Halmer. 2006. The encyclopedia of seeds: Science, technology and uses. CABI, Wallingford, UK.

Bridgen, M.P., E. Olate, and F. Schiappacasse. 2002. Flowering geophytes from Chile. Acta Hort. 570:75-80.

Buerki, S., J.C. Manning, and F. Forest. 2013. Spatio-temporal history of the disjunct family Tecophilaeaceae: A tale involving the colonization of three Mediterranean-type ecosystems. Ann. Bot. 111:361-373.

De la Cuadra, C., A.K. Vidal, S. Lefimil, and L. Mansur. 2016. Temperature effect on seed germination in the genus Leucocoryne (Amaryllidaceae). HortScience 51:412-415.
De la Cuadra, C., A.K. Vidal, and L. Mansur. 2017. Optimal germination temperature for Zephyra compacta (Tecophilaeaceae). HortScience 52:432-435.

Figueroa, J.A., P. León-Lobos, L.A. Cavieres, H.W. Pritchard, and M. Way. 2004. Ecofisiología de semillas en ambientes contrastantes de Chile: Un gradiente desde ecosistemas desérticos a templado-húmedos, p. 81-98. In: M. Cabrera (ed.). Fisiología ecológica y evolutiva de plantas: Mecanismos y respuestas a estrés en los ecosistemas. Ediciones Universidad de Valparaíso, Valparaíso, Chile.

Finch-Savage, W.E. and G. Leubner-Metzger. 2006. Seed dormancy and the control of germination. New Phytol. 171:501-523.

Gutiérrez, J.R. 2008. El desierto florido de la región de Atacama, p. 285-291. In: F.A. Squeo, G. Arancio, and J.R. Gutiérrez (eds.). Libro rojo de la flora nativa y de los sitios prioritarios para su conservación: Región de Atacama. Ediciones Universidad de La Serena, La Serena, Chile.

International Seed Testing Association. 2003. ISTA working sheets on tetrazolium testing. Vol. I. ISTA, Bassersdorf, Switzerland.

Jara, P., G. Arancio, R. Moreno, and M. Carmona 2006. Factores abióticos que influencian la germinación de seis especies herbáceas de la zona árida de Chile. Rev. Chil. Hist. Nat. 79:309-319.

Juliá, C., S. Montecinos, and A. Maldonado. 2008. Características climáticas de la región de Atacama, p. 25-42. In: F.A. Squeo, G. Arancio, and J.R. Gutiérrez (eds.). Libro rojo de la flora nativa y de los sitios prioritarios para su conservación: Región de Atacama. Ediciones Universidad de La Serena, La Serena, Chile.

Kim, H.H. and K. Ohkawa. 2001. Introduction of two Chilean geophytes, Leucocoryne coquimbensis F. Phil. and Zephyra elegans D. Don. as new ornamentals. Acta Hort. 552:179-183.

Muñoz, M. and A. Moreira. 2000. Géneros endémicos monocotiledóneas, Chile. Chloris chilensis. 13 Feb. 2017. <http://www.chlorischile.cl/ monocotiledoneas/zephyra_gen.htm $>$.

Pinto, R. and F. Luebert. 2009. Data on the vascular flora of the coastal desert of Arica and Tarapaca, Chile, and its phytogeographical relationships with southern Peru. Gayana Bot. 66(1):28-49.

Ravenna, P. 1988. New or noteworthy Tecophilaeaceae. Phytologia 64:288-289.

Ravenna, P., S. Teillier, J. Macaya, R. Rodríguez, and O. Zöllner. 1998. Categorías de conservación de las plantas bulbosas nativas de Chile. Bol. Mus. Nac. Hist. Nat. 47:47-68.

Ritz, C., C.B. Pipper, and J.C. Streibig. 2013. Analysis of germination data from agricultural experiments. Eur. J. Agron. 45:1-6.

Ritz, C. and J.C. Streibig. 2005. Bioassay analysis using R. Journal of Statistical Software 12 $<\mathrm{http} / / /$ www.bioassay.dk $>$.

Schiappacasse, F., P. Peñailillo, P. Yáñez, and M. Bridgen. 2005. Propagation studies on Chilean geophytes. Acta Hort. 673:121-126.

Simpson, M.G. and P.J. Rudall. 1998. Tecophilaeaceae, p. 429-436. In: K. Kubitzki (ed.). The families and genera of vascular plants III. Flowering plants. Monocotyledons. Lilianae (except Orchidaceae). Springer, Heidelberg, Germany.

Squeo, F.A., M.T.K. Arroyo, A. Marticorena, G. Arancio, M. Muñoz-Schick, M. Negritto, G. Rojas, M. Rosas, R. Rodríguez, A.M. Humaña, E. Barrera, and C. Marticorena. 2008. Catálogo 
de la flora vascular de la región de Atacama, p. 97-120. In: F.A. Squeo, G. Arancio, and J.R. Gutiérrez (eds.). Libro rojo de la flora nativa y de los sitios prioritarios para su conservación: Región de Atacama. Ediciones Universidad de La Serena, La Serena, Chile.

Vidal, A.K., D.S. Han, M. Nakano, and Y. Niimi. 2012. Decreased time from seed to flowering corm size in Zephyra elegans via in vitro cultivation. Cien. Inv. Agr. 39:577584.

Vidiella, P.E. and J.J. Armesto. 1989. Emergence of ephemeral plant species from the north-central Chilean desert in response to experimental irrigation. Rev. Chil. Hist. Nat. 62:99-107.
Vidiella, P.E., J.J. Armesto, and J.R. Gutiérrez. 1999. Vegetation changes and sequential flowering after rain in the southern Atacama Desert. J. Arid Environ. 43:449-458.

Yañez, P., H. Ohno, and K. Ohkawa. 2005. Temperature effects on corm dormancy and growth of Zephyra elegans D.Don. Scientia Hort. 105:127-136. 